IRSH 50 (2005), pp. 373-397 DOI: I0.1017/S0020859005002 I 54

(C) 2005 Internationaal Instituut voor Sociale Geschiedenis

\title{
An Imagined Geography: Ideology, Urban Space, and Protest in the Creation of Barcelona's "Chinatown", c. $1835-1936^{*}$
}

\author{
CHRIS EALHAM
}

Summary: Henri Lefebvre famously seized upon the duality of the modern city: how for some it is a space of play and liberation, and for others a centre for power and repression. This article explores this duality through an analysis of the changing historical geography of Barcelona's Raval district, an inner-city working-class community and the birthplace of Catalan industrialization. From the I920s onwards, elite groups and social commentators defined the Raval as Barcelona's "Chinatown", an imagined geography that continues to influence historical representations of the area. Through a social history of the Raval, it is argued that the "Chinatown" myth served specific political ends, that it formed part of a cultural project to impose a slum myth on Barcelona's most important and most rebellious working class district. The article concludes with an analysis of how this "moral geography" culminated in far-reaching plans for the moral and physical reordering of the Raval for the benefit of urban elites.

"Ah Barcelona, if you had any shame not a single house would remain standing [in 'Chinatown'].” Rafael Nogueras i Oller, El Carrer del Migdia. Oda número 2 a Barcelona

"[...] the democratic character of a regime is identifiable by its attitude towards the city, urban 'liberties' and urban reality, and therefore towards segregation".

Henri Lefebvre

\section{INTRODUCTION}

Henri Lefebvre famously seized upon the duality of the modern city: how for some it is a space of opportunity, play, and liberation, while for others

\footnotetext{
* My interest in the study began during the two-year period when I lived in Barcelona as a doctoral student. For some of this time I resided in the Raval, where I witnessed the beginnings of "gentrification" ahead of the 1992 Olympic Games. In subsequent trips to Barcelona, I discovered that growing numbers of my favourite haunts in the Raval had disappeared under the pencils of the city planners and the bulldozers of the construction companies. I'm grateful to Helen Graham for her comments on an earlier draft of this paper.
} 
it is a centre for power, control, and repression. ${ }^{\mathrm{I}}$ This article explores this duality through an analysis of the changing historical geography of Barcelona's Raval district, an inner-city working-class community and the birthplace of the Catalan industrial revolution.

For Barcelona, the decades that followed the i830s were a period of vertiginous expansion of urban-industrial space which meant that by 1930 the Catalan capital was the only Spanish city to boast a population of I million. In this unplanned and unregulated urbanization process, new districts appeared almost overnight, conjured up by property speculators and landlords. From the mid-I920s onwards, a range of social commentators - journalists, physicians, historians, ${ }^{2}$ local authorities, business groups, and reformist trade-union leaders - began talking about a new part of the city - "Chinatown" (Barrio Chino). Yet Chinatown was an imagined geography, something that was graphically underlined by the fact that, unlike the other "Chinatowns" in London and North America, there were no Chinese immigrants in Barcelona's Chinatown. Rather, Chinatown discourse was a slum myth propagated by a series of social elites who were increasingly concerned about the threat posed by the inner-city area to their vision of urban governance. The slum and "underworld" myth of Chinatown continues to influence historical and spatial representations today, ${ }^{3}$ and highlights the tendency among many academic specialists to view working-class districts as inherently chaotic and disorganized. 4

The first part of this article will explore the origins and development of Chinatown as a social and cultural construct and how it was imposed on the Raval. I will then go on to discuss the social and political history of the Raval, in particular its importance as a centre of social protest and

I. Henri Lefebvre, La production de l'espace (Paris, I974; [The Production of Space, Oxford, I991]). For an exploration of this process in relation to Barcelona, see Chris Ealham, Class, Culture and Conflict in Barcelona, I898-1937 (London, 2005), esp. chs I and 2.

2. In the I950s, the Francoist historian, Eduardo Comín Colomer, described the area as "intricate and always mysterious"; Historia del anarquismo español, 2 vols (Barcelona, 1956), vol. 2, p. I 34. For a brief history of the area, see Gary Wray McDonogh, "The Geography of Evil: Barcelona's Barrio Chino", Anthropological Quarterly, 60:4, pp. I74-184.

3. See, for instance, Enric Ucelay da Ucelay and Dorsey Boatwright, "La dona del 'Barrio Chino'. La imatge dels baixos fons i la revista 'El Escándalo'”, L'Avenç, 76 (1984), pp. 26-34; Donald McNeill, Urban Change and the European Left: Tales from the New Barcelona (London, 1999), pp. 25, 3 I; Maria Amàlia Pradas, "Pistoles i pistolers. El mapa de la violència a la Barcelona dels anys 1920", L'Avenç, 285 (2003), pp. 13-20.

4. This view can be traced to the Chicago School of "urban sociology"; see, for example, Robert Park et al., The City: Suggestions for Investigation of Human Behaviour in the Urban Environment (Chicago, IL, I925). Belying their radical veneer, postmodern perspectives lend strength to this trend. According to Jordana Mendelson, Chinatown "corresponds to Michel Foucault's concept of 'heterotopy', a disordered, abnormal space”; Jordana Mendelson, "Una tarde en Barcelona", in idem and Juan José Lahuerta (eds), Margaret Michaelis: Fotografía, vanguardia y política en la Barcelona de la República (Barcelona, I998), p. 37. 
contestation. And finally I will assess the historic significance of Chinatown discourse as a "moral geography", or a "geography of fear", that tells us a great deal about the consciousness of urban elites in a given space at a given time. ${ }^{6}$ Therefore, while Barcelona's Chinatown may have been an invented space, with an imaginary geography and history, for the urban elites it was all too real: it was a landscape of disorder and terror. ${ }^{7}$ Thus, we will see that this exclusionary Chinatown discourse had specific political uses: its topophobic obsessions justified official projects for "cleansing" the Raval's "diseased" streets, which were to be placed under new surveillance and restructured, both physically and morally.

\section{THE ORIGINS OF THE CHINATOWN LEGEND}

The term was first coined in 1925 by Paco Madrid, a young journalist on El Escándalo ("The Scandal”), an ephemeral Barcelona weekly newspaper that was briefly resurrected in 1933 as iEscándolo! ("Scandal!"). ${ }^{8}$ Madrid had seen a film about San Francisco's Chinatown, and decided that it was an appropriate label for the Raval neighbourhood. 9 For Madrid, Chinatown was "the city's ulcer [...] the refuge of bad people", and the "underworld" (bajos fondos), a "forbidden zone far worse that anything in Marseilles, Genoa or the East End of London". ${ }^{\text {1० }}$

Such themes were developed avidly by Madrid's journalist colleagues in El Escándalo, Chinatown being described successively as "the district of sinners, crooks and toughs", a "maggot hill”, a "cesspit and cavern, a den of criminals", and other "social detritus". ${ }^{\text {I }}$ Chinatown was fetishized, endowed with causal powers, apparently destroying all moral and physical life within it. It was "a terrible centre for infection", "the pestulant bottom of a sewer", with "its smell of sin and affliction". ${ }^{12}$ Many of the area's

5. According to Felix Driver, the significance of this "moral geography" is that it "unite[s] [other] discourses on morality, health and space"; Felix Driver, "Moral Geographies: Social Science and the Urban Environment in Mid-Nineteenth Century England", Transactions: Institute of British Geographers, I 3 (1988), pp. 275-287. For a more detailed study, see Ruth Harris, Murders and Madness: Medicine, Law and Society in the Fin de Siècle (New York, 1989). 6. James Kneale, “'A Problem of Supervision': Moral Geographies of the Nineteenth-Century British Public House”, Journal of Historical Geography, 25 (I999), pp. 333-348.

7. See Chris Ealham, "Class and the City: Spatial Memories of Pleasure and Danger in Barcelona, I9I4-23”, Oral History, 29 (200I), pp. 33-47.

8. El Escándolo, 22 October 1925. Paco Madrid also wrote a book on the area, with the sensational title "Blood in Atarazanas": Sangre en Atarazanas (Barcelona, I926).

9. Paco Madrid's writings reflected the fact that the big US city was, by the I920s, increasingly the chronotype for urban growth in Barcelona, where the growing influence of the North American way of life was reflected in the craving for Hollywood movies, North American music, dress, and drinks.

10. El Escándolo, 22 October 1925; Madrid, Sangre en Atarazanas, p. 9.

I I. El Escándolo, I 3 and 20 May, is July 1926.

I2. El Escándolo, I 3 and 20 May 1926. 
inhabitants had mutated into a subhuman race. One intrepid El Escándalo reporter ventured into a Chinatown bar and described its clientele thus: "Everyone has funereal features, the look of having recently been in hospital, the appearance of death [...]. They don't eat. They nourish themselves with alcohol, morphine, ether, 'coke' and wine." ${ }^{3}$

These motifs were taken up by the popular press in a stream of sensationalist and frequently prurient newspaper articles that was consumed voraciously by a largely disapproving but highly curious middle-class readership. ${ }^{14}$ Very quickly, the term, Chinatown, entered into everyday usage in the city, becoming synonymous with immorality and crime. Chinatown was portrayed as an alien space: it was the "product of exportation" with "very little local character", ${ }^{15}$ which defied the mores and civic spirit that prevailed in the rest of the city: it "stains the good name of Barcelona", ${ }^{6}$ "it is impossible to understand how anyone can live there". ${ }^{17}$ Perhaps surprisingly, this discourse also found an echo among left-wing groups, in particular, social-democratic groups, whose stress on working-class respectability made them receptive to warnings about the dangers of the "underworld" in Chinatown. ${ }^{8}$ Chinatown discourse even resonated within some anarchist circles. ${ }^{19}$

It is all too easy to dismiss Chinatown moral panics, with their highly ideological content and their hysterical tone. Certainly, this discourse, described by one commentator as a "distorting mirror" lacks sociological validity. ${ }^{20}$ Moreover, by focusing exclusively on moral categories, Chinatown discourse ignored material factors and the central role played by the Raval in Barcelona's economic and historical geography. ${ }^{2 \mathrm{I}}$

13. El Escándolo, 7 and 14 October 1926.

I4. See headlines such as "Panic in Chinatown" and "Cocaine! The Secrets of the Drug", in ¡Escándalo!, 5 September 1933; see also articles in L’Opinió, 26 March, 22 September 1933; La Publicitat, I6 August 1933, I I, I 8 April 1934; La Vanguardia, 26 April I934, Io November 1935. These images were also propagated through novels, such as Domènec de Bellmunt, L'Angel Bohemi (Barcelona, 1935), and urban travelogues, such as idem, Les Catacumbes de Barcelona (Barcelona, 1930), especially pp. 73-82, and Josep Maria Planes, Nits de Barcelona (Barcelona, I93I).

is. ¡Escándalo!, s September 1933 .

16. Guillermo López, Barcelona sucia. Artículos de malas costumbres (Barcelona, n.d.), p. 24.

17. El Escándolo, 20 May 1926.

18. See, for instance, Justicia Social, I August I93 I and 29 April 1933.

19. Solidaridad Obrera, 30 May I93 I referred to the area as a "place of public, moral and material decomposition [pudridero]", and of "degeneration and crime", in which "the shameless pimp, the drunk and the crook are the masters of these streets". It should be noted that the "moral panics" of the anarchists were of a different nature to those of the elites, and centred on the fear that the danger posed by the "bourgeois vices" offered in the Raval's brothels and taverns might corrode working-class revolutionary energies. See also Tierra y Libertad, 5 December I93I.

20. Susanna Barrows, Distorting Mirrors: Visions of the Crowd in Late Nineteenth-Century France (New Haven, CT, I981).

21. Front, 30 July 1932. 


\section{A “NURSERY FOR REVOLUTIONARIES”: A SOCIAL AND} POLITICAL HISTORY OF THE RAVAL

The Raval's historical geography was inextricably linked with Barcelona's urban-capitalist development. Indeed, more than any other of Barcelona's districts, the changing rhythms and vicissitudes of the industrialization process were deeply embedded within the Raval. From the i 830 os onwards, the Raval was transformed by Barcelona's first wave of industrialization into the birthplace of the local working class and of the labour movement. As was the case throughout Europe, in this initial phase of industrialization, workers lived and laboured in the same space, generally inhabiting hastily constructed and densely packed tenement blocks close to their workplaces.

The Raval's urban form was initially conditioned by the determination of the central state to limit Barcelona's urban growth to the area inside its medieval walls, which saw the unregulated and unplanned urbanization of an area of fewer than 2.5 square kilometres. By I860, when the Madrid authorities permitted the economic and social forces accumulated within the old city to spill out beyond its walls, the Raval consisted of a randomly arranged web of compact and heavily populated narrow streets and alleys crammed in around the district's factories, workshops, and warehouses, ending at the Barcelona waterfront. Working-class housing and living conditions in the area were already miserable. The typical Raval tenement was four to six stories high, with one family occupying each floor. Each block had a single toilet and a water tap on the ground floor which was shared by all occupants. Such was the pressure on property developers to maximize available space that many of the Raval's narrow streets were perpetually in darkness, while many others allowed no more than a few shafts of sunlight to enter.

It was no surprise that Ildefons Cerdà, a progressive social thinker whose utopian plan for rational urban development became the blueprint for Barcelona's urban development in 1859 , earmarked the Raval's overcrowded and insalubrious tenements for destruction. ${ }^{22}$ Based on the "grid-iron" template, the straight lines of which were characteristic of the nineteenth-century belief in reason and rational-positivist thought, the "Cerdà Plan" promised to introduce a new urban order in the centre of Barcelona through the construction of a vast eixample (extension), which would connect the port with the nearby industrial satellites that had developed beyond the old city walls. For Cerdà, the Eixample would become the core of a new socially inclusive, inter-class, functional city in

22. Cerdà was a parliamentary deputy for Barcelona during the ephemeral First Republic (1868-1874). See Mercedes Nieto de Sangrenís, La I República española en Barcelona (Barcelona, 1974). 
which people from all walks of life would interact amidst a new equality and civic unity. ${ }^{23}$ However, a combination of capital shortages and the political opposition of property owners in the Raval prevented the full implementation of this ambitious plan. While some of the old inner-city slums were sacrificed for the construction of Les Rambles, a central thoroughfare and the new vertebral column of the city that connected the port with the Eixample, housing renewal in the Raval was thwarted.

As industrialization continued, urban conditions were aggravated further. Despite the poor quality of life in this area, the Raval's proximity to factories, workshops, and the docks ensured that it continued to attract migrant workers. Housing shortages and a rising demand for accommodation resulted in shanty dwellings being constructed on the roofs of tenements (barraquisme vertical). Meanwhile, the unregulated housing market meant that rents continued to rise unchecked. From the turn of the century, therefore, economic imperatives resulted in the subdivision of existing housing stock, creating what the local labour movement denounced as "beehives". ${ }^{24}$ Occasionally several families might occupy flats designed for a single family in order to share the burden of rent payments. By 1930, over 230,000 people were packed into the Raval, giving the area a population density of I03,060 inhabitants per square kilometre. Not only was the Raval the most densely inhabited neighbourhood in Barcelona - its population density was almost ten times the city average it was also one of the most heavily populated areas of Europe. ${ }^{25}$

The sanitary consequences of overcrowding were appalling. Diseases like cholera, typhoid, meningitis, and tuberculosis were rife. ${ }^{26}$ This was aggravated further by two factors. Firstly, the Spanish state was slow to develop welfare functions. The social wage was poor and medical services were largely nonexistent. Secondly, the Raval's landlords, although this terms dignifies what were really slum-lords, were extremely powerful locally: they dominated the Cámara Oficial de la Propiedad Urbana de Barcelona (COPUB/Barcelona Chamber of Urban Property), the main landlords' association in the city, and they had an influential voice in

23. Laboratori d'Urbanisme, Treballs sobre Cerdà $i$ Barcelona (Barcelona, 1992).

24. Jaume Artigas i Vidal et al., El Raval. Història d'un barri servidor d'una ciutat (Barcelona, I980), p. 54; Solidaridad Obrera, I4 May I93 I.

25. The number of residents per building in the Raval was approximately twice the Barcelona average. The population of District V, one of Barcelona's eleven administrative districts which essentially corresponded to the Raval, grew from 192,828 in 1900 to 230,107 in 1930; Mercedes Tatjer Mir, "Els barris obrers del centre històric de Barcelona", in José Luis Oyón (ed.), Vida obrera en la Barcelona de entreguerras (Barcelona, I998), p. I6; Jaume Aiguader i Miró, El problema de l'habitació obrera a Barcelona (Barcelona, 1932), p. 6.

26. Lluís Claramunt i Furest, La pesta en el pla de Barcelona (Barcelona, 1933), pp. 6-8; idem, La Lluita contra la Fibra Tifòidea a Catalunya (Barcelona, I933), pp. I89-206; Nick Rider,

"Anarchism, Urbanisation and Social Conflict in Barcelona, 1900-1932" (Ph.D., University of Lancaster, 1987), p. I52. 
Barcelona politics. The position of property owners was, therefore, virtually unchallenged, and the owners enjoyed immense power over their working-class tenants.

World War I marked the beginning of the Raval's economic decline and the end of its status as Barcelona's most important industrial district. Spain was neutral during the war and this placed Barcelona's capitalists in a privileged position, allowing them to trade with both belligerent camps. ${ }^{27}$ The result was a vast industrial and urban revolution, which continued into the I920s with the so-called "Second Industrial Revolution", that changed Barcelona's urban geography beyond recognition. Modern factories were established across Barcelona's expanding industrial hinterland, and a new "red belt" of working-class neighbourhoods emerged on the margins of the city as industry was spatially reorganized. Although a significant amount of industry remained in the Raval - for instance, there were several small textile factories in the area - this was not as competitive and dynamic as the bigger factories on the outskirts of the city. Moreover, textile production, which was associated with early industrialization, merely underlined the Raval's waning position within the local economy.

As industries relocated away from the Raval, the area gained a new reputation as a centre for popular leisure. The Raval's nightlife already enjoyed a certain standing, both locally and beyond. Once more, this was intimately tied to Barcelona's changing historical geography: during the years before the World Exhibition in $\mathrm{r} 888$, when mass migration had generated a new demand for urban leisure, numerous cabarets, taverns, and cafés had been established in the Raval to satisfy the demands of the innercity proletariat. In particular, there was a significant amount of prostitution in the area, fuelled by the high demand for sexual services among migrant male workers, as well as the proximity of a busy port and the absence of stable employment opportunities for women in the city. ${ }^{28}$

World War I accentuated these features of social life in the Raval. As the belle époque ended in Paris, Barcelona acquired the nickname of the "Paris of the South". The international "party set" of idle rich, playboys, and adventurers decamped to neutral Barcelona and converted it into their new playground. They were followed by a varied group of individuals who, for one reason or another, wanted to escape the war, and which included racketeers, gangsters, and drug smugglers. Draft dodgers and professional revolutionaries also came, the most famous of whom was Victor Serge,

27. According to one bourgeois literary figure, World War I "brought the nineteenth century to a close in Barcelona"; Josep María de Sagarra, Memòries, 2 vols (Barcelona, I98 I), vol. I, p. 290. 28. Temma Kaplan, Red City, Blue Period: Social Movements in Picasso's Barcelona (Berkeley, CA, I 992), pp. I I I-I I 2. For a more detailed survey, see Cristina Borderias, "Women Workers in the Barcelona Labour Market, I 856-1936", in Angel Smith (ed.), Red Barcelona: Social Protest and Labour Mobilization in the Twentieth Century (London, 2002), pp. I42-166. 
who captured the flavour of the period in his novel, Naissance de notre force. ${ }^{29}$ The new arrivals stimulated a surge in demand for, and provision of illegal leisure activities, particularly prostitution, and for the first time it proved necessary to import young women to Barcelona via the port to meet the increased demand for sexual services. ${ }^{\circ}$ There was also a rise in the drugs trade, notably opium, and in illegal gaming.

Another characteristic of this period was the emergence of private security groups, some of which organized protection rackets in a city that was awash with guns. As in many other port cities, it had long been relatively easy to acquire firearms in Barcelona, but the wartime expansion of the Spanish arms industry meant that the illegal arms market was flooded and weapons could be obtained very cheaply. Yet, more than anything, these armed security groups flourished due to the growing insecurity of Barcelona's capitalists. ${ }^{31}$ Foreign intelligence agents were very active at this time and they organized several attacks on industrialists and their property in an attempt to sabotage war production..$^{32}$

The general expansion of so-called "underworld" activities during the war provided much of the inspiration for the Chinatown myth in the I920s. It should be noted that the term "underworld" is best treated with caution, not least because it is a morally charged and politically loaded discursive tool. In terms of Barcelona's social relationships, the term is an inadequate sociological tool. First of all, Barcelona's underworld was always socially stratified. Second, the underworld elite had always intersected with Barcelona's "aboveworld" elite and the relationship between the two was mutually supportive. In a sense, this was inevitable owing to the institutionalized corruption of Spain's Restoration monarchy (1875-1923). From the I880s onwards, it was widely recognized by internal police sources that the Barcelona constabulary was heavily implicated in arms smuggling, prostitution, illegal gambling, drugs rackets, and other criminal activities. ${ }^{33}$ By the turn of the century, La policía española, the professional journal of the Spanish police, observed that the main activity of the Barcelona constabulary was the "framing" of innocent

29. According to one local, in World War I, "Barcelona became a haven for all the persecuted agitators from across Europe”; Joan Garriga i Massó, Memòries d'un liberal catalanista (I87I1939) (Barcelona, 1987), pp. 22 I-222.

30. This was described as the "white slave trade" (trata de blanques); see, for instance, El Escándalo, I 4 October 1926.

31. Ealham, "Class and the City", pp. 33-47.

32. Angel Pestaña, Terrorismo en Barcelona (Memorias inéditas) (Barcelona, 1979), pp. 83-96. For a penetrating analysis, see Eduardo González Calleja and Fernando del Rey Reguillo, "Violència política i pistolerisme a la Catalunya de la primera posguerra mundial", L'Avenç, I92 (1995), pp. 34-4I.

33. Waldo López Rodríguez, Proyecto de Reorganización de la Policia de España (Zaragoza, I899), pp. I0-I I. 
citizens, and that the eradication of crime could only be achieved after the incarceration of the city's policemen! ${ }^{34}$

Corruption grew during the wartime economic boom. In business, the dividing line between legal and illegal commerce, a distinction that had never been especially clear anyway, was further blurred. ${ }^{35}$ Professional criminals and the industrial elite occupied the same social space, freely mixing in Barcelona's casinos, upmarket bordellos, and gentlemen's clubs. ${ }^{36}$ Perhaps the most graphic example of the overlap between criminal and official worlds is the case of Barcelona's corrupt chief of police, Bravo Portillo, who worked as a German intelligence agent for part of the war, facilitating information on ship movements to U-boat commanders in Barcelona port. ${ }^{37}$ Bravo Portillo also collaborated with the self-styled "Barón del König", an enigmatic playboy and former German agent who typified the type of adventurer who prospered in wartime Barcelona: together, the Barón and the chief of police organized protection rackets and contract killings and enjoyed the patronage and protection of local authorities and elites. Later, when it emerged that the Barón del König had stimulated demand for his security firm by organizing gun attacks on employers, he was was deported from Spain..$^{38}$

A significant amount of this expanded illegal activity centred on the Raval. ${ }^{39}$ In part, this was because the surge in demand for new places of leisure and pleasure coincided with the area's industrial transition. Thus, many of the Raval's newly vacated warehouses and workshops were hastily converted into cabarets, dance halls, and taverns. ${ }^{4 \circ}$ For instance,

34. La policía española, cited in Pedro Trinidad Fernández, La defensa de la sociedad. Cárcel y delincuencia en España (siglos XVIII-XX) (Madrid, I99I), pp. 298-309.

35. One analyst of the I 920 s reflected that "the classic swindle and the cloudy business deal were the order of the day" in financial circles; José Luis Vila, La vida cotidiana en España durante la dictadura de Primo de Rivera (Barcelona, I984), p. 64. For a case study of one such "deviant" entrepeneur, see Ramón Garriga, Juan March y su tiempo (Barcelona, 1976).

36. Front, 30 July 1932, a dissident communist publication, exposed the existence of upmarket brothels in the Eixample.

37. Solidaridad Obrera, 9 and i June i9r8.

38. The real identity of the "Barón" remains a mystery. According to one former Barcelona police chief, his name was Friederich Stallmann; Manuel Casal Gómez, La "banda negra". Origen y actuación de los pistoleros en Barcelona (1918-192I) (Barcelona, I977), pp. 27-28. There is also speculation that his original surname is believed to have been Colman or Kölmann. To add to the confusion, his nom de guerre is frequently misspelt. Besides working for German secret services, it has also been claimed that the Barón was employed by either British or French intelligence. After his deportation from Spain in May 1920, he apparently settled in Paris, where he dedicated himself to extortion and blackmail, before changing his identity and disappearing without trace; Jordi Ventura, "La personalitat veritable del baró de König", Serra D’Or, September 1970, pp. $8 \mathrm{I}-84$.

39. This was reflected in Jean Genet's I 949 Journal de voleur (The Thief's Journal), inspired by the author's experiences in the area during the interwar period.

40. Pedro Gual Villalbí, Memorias de un industrial de nuestro tiempo (Barcelona, n.d.), pp. I38, I 40. According to Garriga i Massó, "Barcelona was the European city which took over from fin 
"La Criolla", a much-frequented cabaret and brothel, opened in I9Is in a former textile factory..$^{4}$ At the same time, new clandestine establishments were founded, such as opium dens, brothels, and illegal gaming rooms, while several protection agencies were located in and around the area; for example, the Barón del König had an office on Les Rambles, on the edge of the Raval.

Yet notwithstanding all these changes, the Raval continued to be a working-class district. ${ }^{42}$ By 1900 , municipal statistics revealed that onefifth of the city proletariat resided in the Raval. ${ }^{43}$ Moreover, from the I880s onwards, members of the middle and upper classes had left the area for the Eixample, the ordered residential space they idealized as a new city of reason. The confidence of the remaining upper- and middle-class families in the area was rocked by the urban riots of $1909,{ }^{44}$ prompting them to flee the Raval, whereupon their flats were subdivided for multiple occupancy by working-class families. Thereafter, social divisions were increasingly inscribed in the streets and districts of the city: the working class and the bourgeoisie established relatively autonomous patterns of sociability, and there was little contact between these classes outside the factory.

From their vantage point in the Eixample, the elites quite literally looked down nervously upon the Raval as a centre of irrationality populated by what they saw as the "perishing classes". Moreover, in their everyday life in the city, it was difficult for the "men of order" to ignore the Raval's "dangerous classes": we see from Figure i (p. 384) the proximity of the Liceu (no. 9), the Barcelona opera house and the cultural citadel of the city's bourgeoisie, along with many administrative centres (nos 39 and $4 \mathrm{I}$ ) and business offices on Laietana Way (no. 36).

During the I9Ios, the Raval's housing market evolved into an integral element of Barcelona's low-wage, casual economy. ${ }^{45}$ The few better-off

de siècle Paris [...] it was the oasis of Europe, where happiness and joie de vivre were possible"; Memòries, pp. 213-214.

4I. Abel Rebollo et al. (eds), Barcelona rebelde. Guía de una ciudad silenciada (Barcelona, 2003), p. 255 .

42. According to one study of the Raval, the population was of "eminently working-class social composition"; Artigas i Vidal, El Raval, p. 5 r. This view was confirmed by one resident from the interwar era, "they were workers, colliers, stevedores [...]. There were whores, pimps, hoods, but only the minority"; cited in McDonogh, "The Geography of Evil", p. 176.

43. Figures cited in Tatjer Mir, "Els barris obrers [...]", in Oyón, Vida obrera en la Barcelona de entreguerras, pp. I4, 22, 30 .

44. One middle-class observer lamented that "the rebellious masses were masters of the city for eight days"; Garriga i Massó, Memòries, p. I 82.

45. Lluís Claramunt i Furest, Problemes d'urbanisme (Barcelona, 1934), pp. I4-I8; Carme Massana, Indústria, ciutat i propietat. Política económica i propietat urbana a l'Área de Barcelona (1901-1939) (Barcelona, I985), pp. 22, I26-130; Aiguader i Miró, El problema de l'habitació obrera, p. I4; Front, 30 July 1932; Artigas i Vidal, El Raval, pp. 5 Iff. 
workers in the area moved out and the district increasingly catered for the poorest sections of the working class. ${ }^{46}$ One of the area's unique characteristics was its concentration of "doss"- or "flop"-houses which provided rooms for single, male, unskilled migrant labourers who could not afford a deposit for a rented flat. ${ }^{47}$ Several former factories were converted into dosshouses, which consolidated the area's status as a place of transit for migrant workers. ${ }^{4}$ Part of what has been described as the picaresque proletariat of sailors, dockers, and itinerant labourers, ${ }^{49}$ these workers were attracted by the opportunities for casual, sweated labour in the area, especially on the waterfront..$^{\circ}$ The picaresque proletariat was also much enamoured of the raw pleasures available in the cabarets and taverns that gave the Raval its distinctive atmosphere of proletarian bohemia. Such masterless men had little sense of deferred gratification: they worked hard and played harder and rougher still. It was their behaviour that inspired many of the moral panics about the Raval's inhabitants. But alongside the picaresque proletariat there was a much, much larger working-class community, which comprised the bulk of the Raval's population. This relatively sedentary community was far removed from the Chinatown stereotypes of the drug-crazed pimp or the drunken docker. Importantly, despite the internal stratification within the local working class, the social context in the Raval was broadly similar for all workers: they were overwhelmingly unskilled or semiskilled workers with few bargaining resources; they survived on subsistence wages; they lived in unmodernized, overcrowded housing and faced an overarching structure of material coercion in their everyday lives.

It would be wrong, however, to give the impression that Raval was merely a place of misery and despair. Certainly, there was incalculable poverty but, contrary to the Chinatown legend and the portrayal of the area as an unruly space, there was a social and cultural order: it was a rough, aggressive and assertive working-class order. It was this rival order that drove terror into the hearts of urban elites.

46. Tatjer Mir, "Els barris obrers", pp. I4, i9.

47. One dosshouse was known locally as "the three eights" after the number of daily shifts in the beds; Rafael Vidiella, Los de ayer (Barcelona, I938), p. 33 . In some of these flophouses one didn't flop at all: these consisted of large rooms with a rope in the centre against which workers leaned and slept standing up.

48. Conditions were abysmal in old industrial buildings that were not designed for their new purpose; Manuel Gil Maestre, La criminalidad en Barcelona y en las grandes poblaciones (Barcelona, I886), pp. I47-I 57; Paco Villar, Historia y leyenda del Barrio Chino (1900-1992). Crónica y documentos de los bajos fondos de Barcelona (Barcelona, 1996), pp. 37-4I; Joan Busquets Grau, Barcelona. Evolución urbanística de una capital compacta (Madrid, I992), p. 2 I 3 ; Tatjer Mir, "Els barris obrers", p. 29.

49. Peter Linebaugh and Marcus Rediker, The Many-Headed Hydra: Sailors, Slaves, Commoners, and the Hidden History of the Revolutionary Atlantic (Boston, MA, 200I).

50. De Bellmunt, Les Catacumbes de Barcelona, pp. 35-36. 


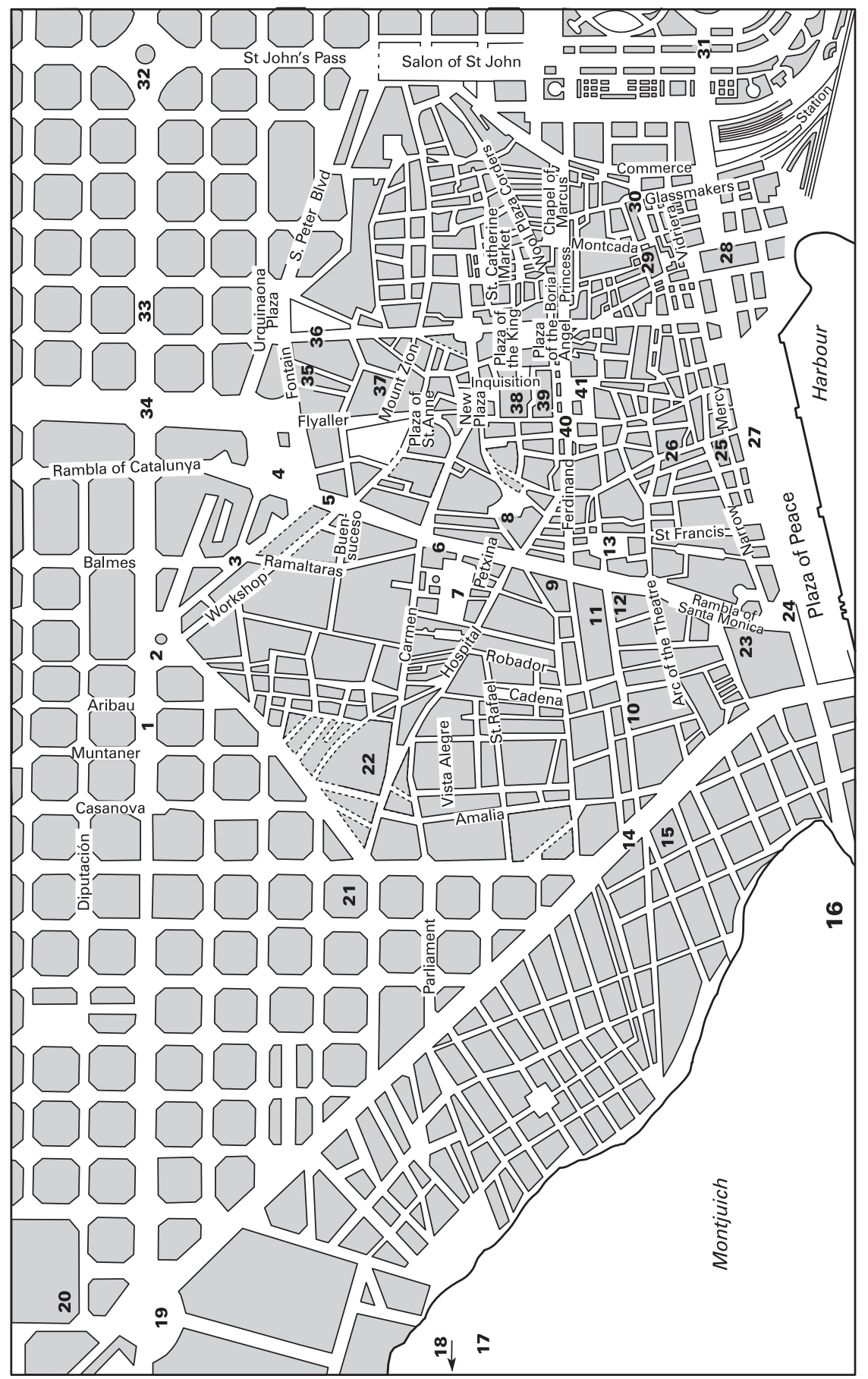


There were various coordinates to this working-class order. Its first dimension was a high degree of sociability. Due to overcrowded housing, the Raval's streets functioned as an extension of the home, resulting in frequent and intense direct human interactions. Also, in response to the material problems of everyday life, workers developed mutual and reciprocal practices. In turn, these rituals fostered extensive social bonds among the community, which was endowed with a fierce spirit of independence. The second central element of this working-class order was a profound sense of local identity. In many respects this was a spatial identity, a sense of attachment to a place, or what Raymond Williams

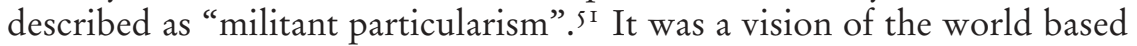
on working-class materiality and practice: it was situated knowledge rooted in urban experience. The strength of this identity reflects the remarkable level of socio-economic and cultural homogeneity that bound the Raval's inhabitants together. ${ }^{52}$

The final element of the Raval's order was a vibrant working-class public sphere. Trade unions were the most important organization within this counter-hegemonic public sphere. The Raval was the capital not just of the local labour movement, but also of the Spanish workers' movement: it was the site of first ever national workers' congress in I 870 and Spain's earliest trade unions were formed here (the socialist Unión General de Trabajadores (UGT/General Workers' Union) was created there in I 888).

51. Raymond Williams, Resources of Hope: Culture, Democracy, Socialism (London, 1989), pp. II $5,242,249$.

52. For the impact of social segregation on consciousness, see Richard Dennis, "People and Housing in Industrial Society", in Michael Pacione (ed.), Historical Geography: Progress and Prospects (London, 1987), p. I91; Richard Harris, "Residential Segregation and Class Formation in the Capitalist City”, Progress in Human Geography, 8 (1984), pp. 26-49.

Figure I. Inner-city Barcelona, in the nineteenth and early twentieth centuries. The map reflects the urban reforms of 1859, 1908-1911, and 1926-1929.

I. The Eixample (Extension), the area of hexagonal-shaped streets; 2. Plaza of the University; 3. Palayo St; 4. Plaza of Catalunya; 5. The Rambla; 6. The Flower Market; 7. Boqueria, St Joseph Market; 8. Church of Pi, St Mary of the Pine Tree; 9. The Lyceum; ro. New Street of the Rambla; I I. Eden Concert; I 2. Güell Palace; I 3. Royal Plaza; I4. The Parallel, Marquis of Duero Avenue; I 5. Pompey Music Hall; 16. Castle of Montjuich; 17. Museum of Catalan Art; 18. Spanish Village; 19. Plaza of Spain; 20. Arenas Bullring; 21. St Anthony Market; 22. Plaza of Padró; 23. Atarazanas Barracks; 24. Columbus Monument; 25. Basilica of the Virgin of Mercy; 26. Avinyo St; 28. Plaza of the Palace; 29. St Mary of the Sea; 30. Born Plaza; 31. Citadel Park; 32. Tetuan Plaza; 33. Main St; 34. Gracia Pass; 35. Telephone and Telegraph Exchange; 36. Laietana Way; 37. Four Cats Café; 38. Cathedral; 39. Provincial government building/Generalitat/Diputación; 40. Plaza of St James; 4I. City Hall.

Map adapted from Temma Kaplan, Red City, Blue Period: Social Movements in Picasso's Barcelona (Berkeley, CA, 1992), pp. 200-20I. Used with permission. 


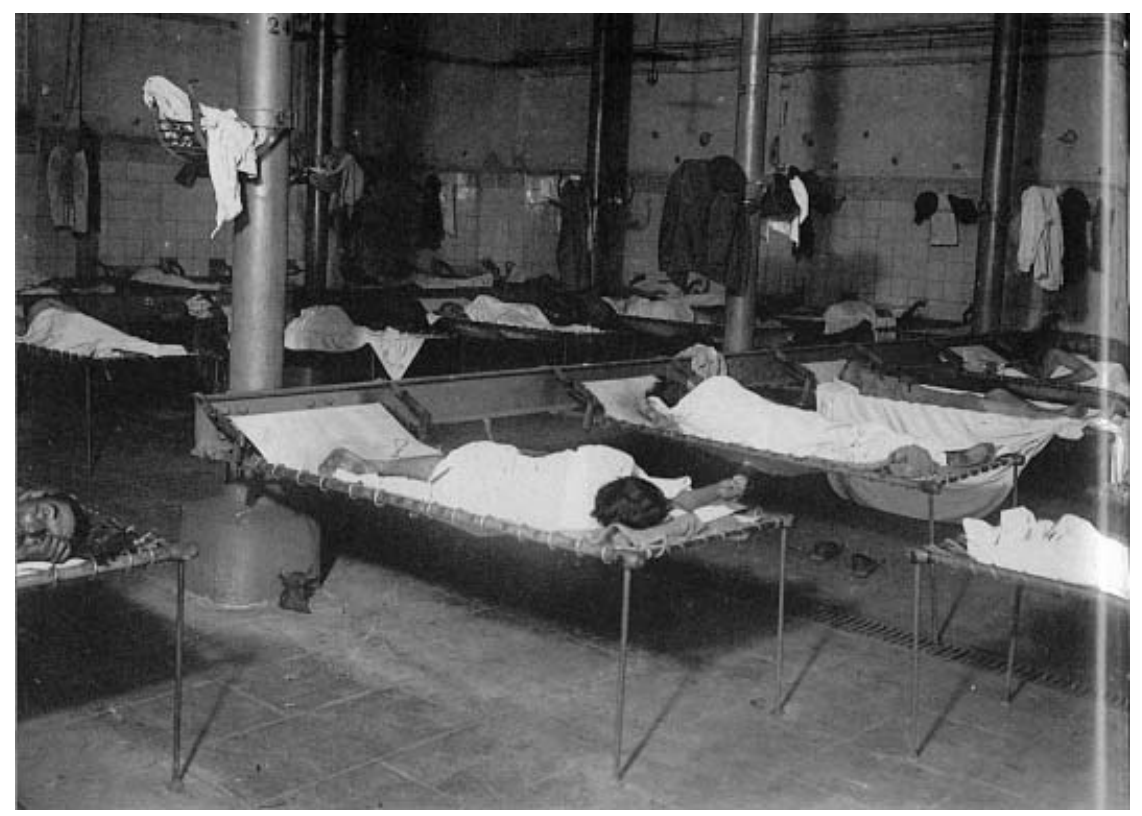

Figure 2. Labourers sleeping in a Raval dosshouse located in a former factory.

Francesc Bonamusa, Pere Gabriel, Josep Lluís Martín Ramos, and Josep Termes, Història Gràfica del Moviment Obrer a Catalunya (Barcelona, 1989), p. I9I. Used with permission.

After the Madrid-based socialist leadership relocated the UGT's headquarters to Madrid in I899, ${ }^{53}$ the Raval became a bastion of Barcelona's popular anarcho-syndicalist movement, which established a network of trade-union offices and social and cultural centres in the area. During times of repression, trade unionists regularly met clandestinely in the neighbourhoods' masculine spaces, such as taverns and bars. ${ }^{54}$

In addition, the Raval was home to a myriad of cooperatives, friendly societies, workers' educational centres, and radical publishing houses and newspapers." This workers' public sphere built upon the Raval's spontaneous sociability, marrying local traditions of autonomy and reciprocity with the new ties of loyalty and affinity produced by workers' organization. The anarcho-syndicalists reaffirmed the Raval's

53. See Xavier Cuadrat, Socialismo y anarquismo en Cataluña (I899-I9II). Los orígenes de la CNT (Madrid, I976); Joaquín Maurín, "Pablo Iglesias y el pabloiglesismo", L’Opinió, 22 December 1928.

54. Emili Salut, Vivers de revolucionaris. Apunts històrics del Districte Cinquè (Barcelona, 1938), pp. I $47-148$.

55. The list is vast. See, for example, Ferran Aisa, Una Història de Barcelona. Ateneu Encicopèdic Popular (1902-1999) (Barcelona, 2000). 
spirit of independence, celebrating the "goodness" of the "pariahs" who inhabited its "streets [that] were stained with so much proletarian blood". ${ }^{6}$ The workers' public sphere also enhanced key features of the neighbourhood's local identity; for instance, one of the local workers' newspapers, which was titled Los Miserables, underscored the material impoverishment of the Raval's inhabitants. ${ }^{57}$ For many of the area's residents, this was a "space of hope"; ${ }^{8}$ for the anarcho-syndicalists, it was a revolutionary heartland, a centre for emancipatory urban politics, a "nursery for revolutionaries". 59 Meanwhile, middle-class political parties only had a token presence in the Raval, something that served only to increase elite suspicions of the area. ${ }^{60}$

Inevitably, the Raval was the site of violent conflicts between labour and capital and of state repression. ${ }^{61}$ Local traditions of direct-action protest, rioting, and barricade building extended back to the 1830 s: in the I $835 \mathrm{La}$ Bonaplata riot, workers destroyed new technology which they perceived as a threat to their job security. Church property was also attacked and social protest frequently acquired an anti-clerical thrust. Direct-action protest was heavily inscribed in the collective memory of local workers and their urban insurgency endured well into the twentieth century. In I902, Spain's first general strike had its epicentre in the Raval: barricades were erected and food was forcibly requisitioned from bakeries and markets in a manner that resembled the consumption riots of the nineteenth century. This strike, like many later conflicts, drew strength from the area's solidarities and its aggressive street culture: large crowds consisting of men, women, and children took to the streets to defend their neighbourhood from outside agencies, such as the police. When the security forces attempted to enter the area, they came under sustained attack in the streets, missiles raining down upon them from the windows and rooftops of the tenements. The protest ended with military repression and several deaths. ${ }^{62}$ The Raval rose again in 1909, when anti-war protests culminated in full-scale urban insurrection, barricades, street-fighting, and

56. Solidaridad Obrera, 9 April I933, 20 March 1934, is September I935; La Revista Blanca, I 9 April 1935 .

57. Josep Maria Huertas Claveria, "La política en un barri apolític”, in Claudio Zulián (ed.), Escenes del Raval (Barcelona, I999), p. 30.

58. David Harvey, Spaces of Hope (Edinburgh, 2000).

59. Salut, Vivers de revolucionaris.

60. Isidre Molas, Lliga Catalana. Un estudi d'Estasiologia, 2 vols (Barcelona, I972), vol. I, p. 304 .

6r. See the pioneering studies by Pere López Sánchez: El centro histórico: un lugar para el conflicto (Barcelona, I986), and Un verano con mil julios y otras estaciones. Barcelona: de la Reforma Interior a la Revolución de Julio de 1909 (Madrid, 1993).

62. Joaquín Romero Maura, "La Rosa del Fuego". Republicanos y anarquistas: la política de los obreros barceloneses entre el desastre colonial y la Semana Trágica, I899-I909 (Barcelona, 1989), pp. 2 I0-2 I I; Angel Duarte, "Entre el mito y la realidad. Barcelona I902”, Ayer, 4 (I99I), p. I66. 
widespread church burning across Barcelona. ${ }^{63}$ Evoking images of the Paris Commune, the last remaining barricades were obliterated with cannon-fire. Before World War I, then, when Barcelona earned the nickname "the Paris of the South", the Catalan capital had already inherited the mantle of nineteenth-century Paris as the revolutionary capital of Europe. And within the city, not without justification, revolutionaries predicted that it was from within the Raval that "the exterminating angels of the bourgeoisie will rise up". ${ }^{64}$

The final set of mobilizations in the Raval prior to the creation of the Chinatown myth came at the end of World War I. The war-time boom enhanced the size of the local working class and bolstered the ranks of the anarcho-syndicalist Confederación Nacional del Trabajo (CNT/National Confederation of Labour), as Barcelona became possibly the most unionized city in Europe. ${ }^{65}$ Even some of the Raval's musicians were unionized, and when they went on strike for wage increases in 1922 they successfully closed down around twenty cabaret venues.

In response to the newly concentrated power of labour, when the war ended the most militant sections of the Catalan bourgeoisie resorted to union-busting tactics, including extra-judicial assassination. There followed the so-called "years of gun law" (años del pistolerismo), when rightwing gunmen and fortune-hunters, such as the Barón del König, were bankrolled by industrialists to murder trade unionists. Together with the disgraced former police chief Bravo Portillo, Barón del König organized the "black gang" (banda negra), which assassinated a number of leading worker-activists. ${ }^{66}$ During the pistolerismo era, the Raval was the site of low-intensity urban-guerrilla warfare and, unsurprisingly, most of the gun-related deaths in Barcelona at this time occurred here. ${ }^{67}$ In a bid to defend the CNT's space in society, the unions and anarchist groups formed rival "action squads" to hit back against right-wing gunmen and their sponsors. Several of these action squads were based in the Raval, where they benefited from the active or passive support of local workers; as a minimum, they knew they would not be betrayed to the police by

63. On I909, see Pere López Sánchez, Un verano con mil julios y otras estaciones. Barcelona: de la Reforma Interior a la Revolución de Julio de 1909 (Madrid, I993); Romero Maura, "La Rosa del Fuego"; Joan Connelly Ullman, The Tragic Week: A Study of Anticlericalism in Spain, I8751912 (Cambridge, MA, I968). For a more recent analysis of general strikes in Barcelona, see Angel Smith, "Anarchism, the General Strike and the Barcelona Labour Movement", European History Quarterly, 27 (1997), pp. 5-40.

64. Vidiella, Los de ayer, p. 93.

65. Ealham, "Class and the City", pp. 33-47.

66. Bravo Portillo was known popularly as a "pimp" (xulo); Montserrat Roig, Rafael Vidiella, l'aventura de la revolució (Barcelona, I976), p. 40. His assassination prompted an outpouring of popular celebrations and parties were held across the city. See Adolfo Bueso, Recuerdos de un cenetista, 2 vols (l'Esplugues de Llobregat, I976), vol. I, pp. I26-I 28.

67. Amàlia Pradas, "Pistoles i pistolers", p. I 5 . 


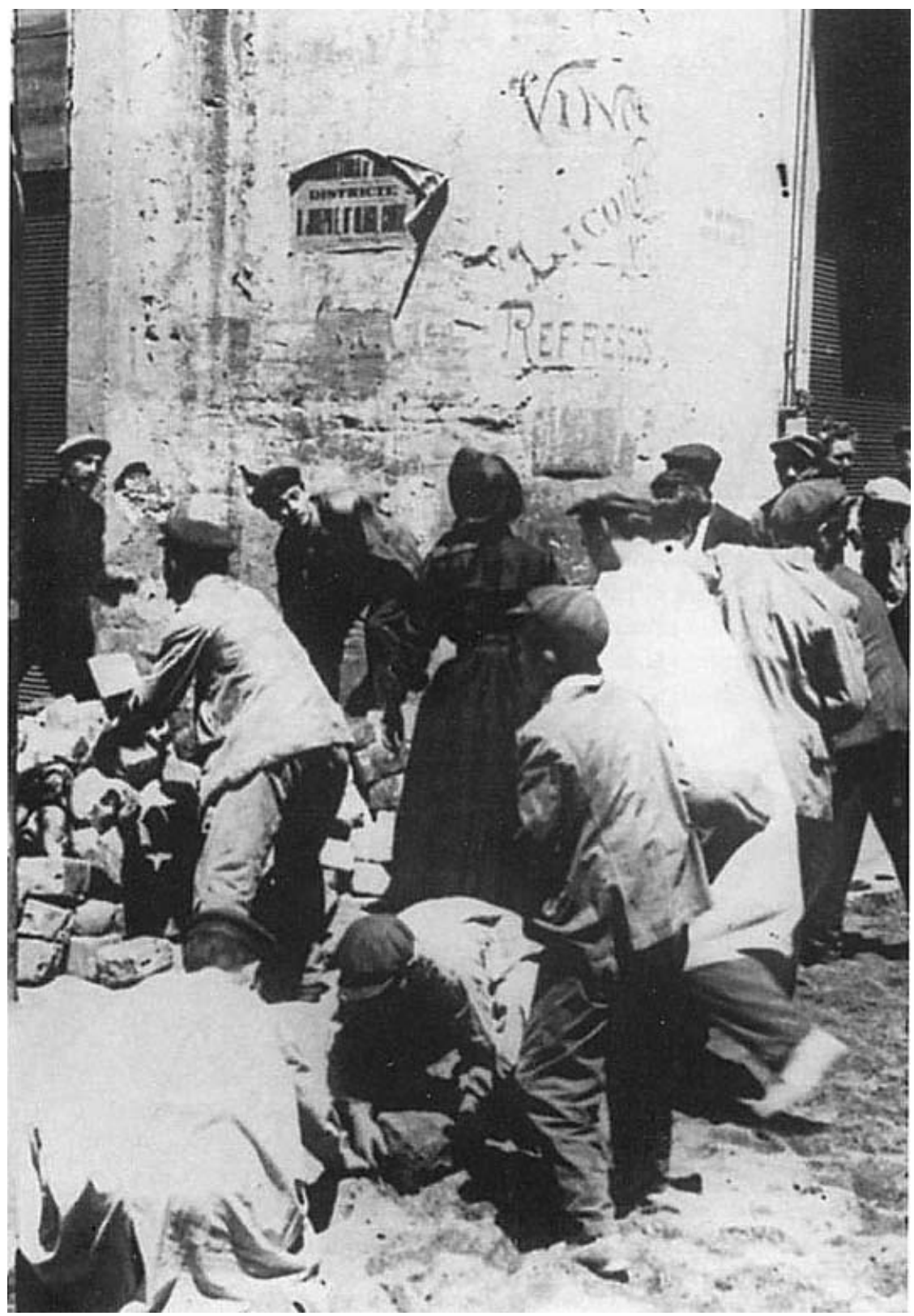

Figure 3. Members of the community - men, women and children - constructing a barricade in the Raval during the July I909 "Tragic Week".

Copyright: Ballell, Arxin Fotogràfic de l'Arxin Històric de la Ciutat de Barcelona. Used with permission. 
members of the community who recognized them as their own, as a product of the local environment.

The Raval was, therefore, the most vibrant and defiant working-class neighbourhood in the city. Contrary to the Chinatown legend, it was not the case that the Raval was immoral; it was more that the neighbourhood rejected the morality of the urban elites, its rich local identity proving largely impermeable to bourgeois cultural politics. And this rebel culture was embedded within the Raval's narrow, randomly organized streets, which proved difficult for the authorities to regulate and submit to external control. This was the genuine source of the alarm felt by urban elites, who were fully apprised of the serious problems that the loyalties and solidarities of the Raval posed for the urban order. ${ }^{68}$ Here also lies the key to the origins of the Chinatown myth: in the consciousness and in the collective memory of Barcelona's men of order, the Raval was an inherently refractory and disorderly place. The social construction of Chinatown, therefore, conveniently allowed a slum myth to be imposed on Barcelona's oldest and most rebellious working-class community.

\section{THE POLITICAL USES OF THE CHINATOWN MYTH}

Chinatown discourse was more than an outpouring of dystopian despair. It served an array of political uses: it was a declaration of the readiness of urban elites to intervene in the social organization of the city in order to reclaim both symbolic and physical space, ${ }^{69}$ and it formed part of a project to assert control over the local working class, both inside and outside the workplace..$^{70}$ In other terms, Chinatown was part of a hegemonic struggle, a means of exerting cultural domination and reasserting state authority over a defiant community, a conservative ideological weapon in a "cultural politics of place". ${ }^{11}$ It therefore justified social and state intervention in the Raval in an effort to interrupt and break down the profound working-class resistances, traditions, and identities in the area. This can be seen in the manner in which the Raval was constructed as a "wild land" or an unruly wilderness which, accordingly, had to be tamed. ${ }^{72}$ And, because, according to Chinatown discourse, the Raval lacked moral content, civilization had

68. For example, El Liberal, 4 September I901, spoke of the "close solidarity" of "the worker masses".

69. See K.J. Anderson, "Cultural Hegemony and the Race-Definition Process in Chinatown, Vancouver: 1880-1980", Society and Space, 6 (1988), pp. I 27-149.

70. For Driver, "moral geographies" were "part of a process of appropriation (and, hence, regulation) of the spaces of everyday life [...], participants in the reconstruction of urban space"; "Moral geographies", p. 276.

71. David Harvey, Justice, Nature and the Geography of Difference (Cambridge, MA, 1996), pp. $321-322$.

72. For a discussion, see ibid., p. 320. 
to be imported, thus creating a new moral landscape. Accordingly, Chinatown discourse would have profound material consequences for the Raval.

One of the most striking political features of Chinatown discourse is that it provided common ground for Barcelona's fragmented and factionalized elites. These elites were politically divided among liberals, conservatives, centralists, Home Rulers (autonomists), catholics, anticlericals, republicans, and monarchists. Although liberals and conservatives might have disagreed over the balance between reform and repression, Chinatown discourse reflected shared views among the men of order about the desirability of a new disciplinary order, about the seriousness of the threat from below, and about the importance of control and vigilance. Chinatown moral panics placed the accent on the urgent need to resist the "diseased mob" that had escaped the control of authority and of all reasonable morality. If left unchecked, this "internal enemy" would "infect" the rest of the city, damage family life and destroy urban civilization as it existed.73 Inevitably, given such high stakes, the men of order would have to close ranks.

Equally, the ambiguities of Chinatown discourse meant that it could appeal to different elite factions. Understandably, there was disagreement over the causes of Chinatown - conservatives saw it in quite narrow moral terms, as a consequence of the erosion of old traditional values and patterns of social control occasioned by the advent of mass society and the massified city, ${ }^{74}$ wheras liberal opinion invoked Chinatown as evidence of the need for a far-reaching reform programme. However, Spanish liberalism was anything but indulgent: liberals saw "order" as a precondition for reform and they were often as insistent and draconian as conservatives in their readiness to pacify Chinatown.75

El Escándolo typified this trend within Spanish liberalism. Part of Spain's growing anti-monarchist opposition in the I920s, El Escándolo was identified with progressive opinion or, what it called, "a liberal conception of life"; not without humour, the paper's subtitle described it as a "modern weekly of sensationalist articles and pacifist struggle". ${ }^{6}$ The paper championed a modern style of journalism that charted the growth of urban society: its contributors were drawn heavily from the professional middle class and included physicians, lawyers, and civil servants; the focus of the paper was also explicitly urban - all its journalists were obsessed

73. López, Barcelona sucia, foresaw that an unchecked Chinatown could corrupt youth and result in "the end of Spain"; pp. $54-56,56$.

74. Gual Villalbí, Memorias, pp. I32-136, I69.

75. Paco Madrid, Ocho meses y un día en el gobierno civil de Barcelona (Barcelona, 1932), pp. I43-I45, I7I-2I 4 .

76. El Escándolo, 1० December 1926. 
with city life: they revelled in and were simultaneously repelled by the darker side of the city. Significantly, however, alongside this air of political modernity, the spatial commentary in El Escándolo was heavily inflected by the discourse of nineteenth-century urban reformers and moralists and revealed an unswerving fixation with the preservation of order.

The united front of the elites can be seen in the way in which liberals, conservatives, and Catalan nationalists agreed that Chinatown was at variance with the prevailing mores and norms of Barcelona: it was described as being "independent of the rest of Barcelona",77 as having morally seceded from the city. In this respect, the Chinatown myth was the culmination of four decades of elite disquiet about the nefarious effects of urbanization on egoism, criminality, immorality, and alcoholism; it constituted a restatement of the "dangerous-classes" discourse of the I880s, an older Europe-wide language of power that encapsulated a profound pessimism about the consequences of urbanization..$^{7}$ Indeed, in the case of Barcelona, fears of the dangerous classes had long focused on the Raval;79 as El Escándolo observed, the area was "the longstanding concern of the sensible people and the men of order". 80

Liberals and conservatives also endorsed contemporary western racial prejudices about the assumed deviancy and dirtiness of Chinese immigrants. Although there was no Chinese community in Barcelona at this time, anti-oriental racism was very much in evidence among local politicians and elites. Even radical left-wing republicans, such as the L'Opinió group, denounced Japanese imperialism as the "yellow peril". ${ }^{81}$ There was, moreover, a local tradition of invoking racial categories to exoticize specific spaces that challenged the urban order in Barcelona: in the I 880 s, a shanty community established by homeless migrant workers on the beach, near the major industrial district of Poblenou, was christened Peking (Pekin) by local commentators, some forty-odd years before the invention of Chinatown.

Catalan nationalists were especially fond of externalizing social problems. They, like many other elite groups, also adopted a colonialtype discourse to racialize the working class - both Catalan and migrant along with social problems and conflicts. Hence, they invariably referred to Chinatown as the Barrio Chino, in Spanish and not in Catalan, the suggestion being that the area's problems were explicable in terms of

77. El Escándolo, 2 I January 1926.

78. López, Barcelona sucia, is the best example of this discourse applied to Barcelona. For Europe, see Andrew Lees, Cities Perceived: Urban Society in European and American Thought, I820-I940 (Manchester, I985), esp. chs 5-7.

79. Before World War I, the Raval was described by one local liberal paper as an "inferno";

L'Esquella de la Torratxa, i I April i9i3.

80. El Escándolo, 20 May 1926.

81. L’Opinió, i 8 May 1932. 
migration from Spain's depressed agricultural regions. Some Catalan nationalists even described the Raval as "Barcelona's Andalusia". ${ }^{22}$ The great attraction of externalizing the Raval was that it avoided asking awkward questions about social justice, urban crisis, and the inequalities between rich and poor districts.

Official concern with Chinatown reached its peak in the I930s, during the Second Republic, when several former contributors to El Escándolo occupied important political positions. ${ }^{83}$ A broad political consensus formed around the "problem" of Chinatown as the single most important challenge to Barcelona's social order. Chinatown became the abiding concern for a coalition of middle-class "experts". In the vanguard were members of the medical profession, both physicians and psychiatrists, who routinely employed medical language to diagnose the Raval as a "diseased" space. $^{84}$ A good example of this current was Dr Jaume Aiguader i Miró, a former social democrat and Barcelona's mayor during the Republic. The author of several studies on housing and social conditions in the city, Aiguader i Miró denounced the "perversity" of the Raval. ${ }^{85}$ This message was amplified further by housing reformers, urban planners, criminologists, municipal administrators, local politicians, and social reformers. Chinatown panics also found an echo in the labour movement in the I930s, in no small part due to the El Escándolo journalists, several of whom had connections with Barcelona's small reformist trade unions and political groups, such as the Unió Socialista de Catalunya (USC/Socialist Union of Catalonia). For these social democrats, not only were the crude, hedonistic pleasures of Chinatown an affront to their sense of proletarian respectability and deferred gratification, they also claimed that their anarchist rivals were in alliance with "underground parasites" and a lumpenproletariat of "professional layabouts and thieves". ${ }^{86}$

For this broad coalition of groups, the great political advantage of Chinatown was that it allowed for a variety of distinct and separate challenges to the urban order (revolutionaries, professional criminals, drug

82. L'Opinió, 22 September 1933, 7 April, 9 August 1934.

83. For instance, Paco Madrid was secretary to various Barcelona civil governors, including fellow El Escándolo writer, Carles Esplá, Marcelino Domingo was a cabinet minister on more than one occasion, while Angel Samblancat was elected to parliament at the start of the Republic. 84. One liberal medical reformer argued that Chinatown had to be demolished on moral and health grounds, an act of "moral and material cleansing" that would end illness linked to overcrowded housing and "nocturnal life in cabarets and other places of doubtful morality"; Claramunt i Furest, Problemes d'urbanisme, pp. 9, I4.

85. A physician by training, Aiguader i Miró had published widely on "the working-class condition" and housing matters; see his El problema de l'habitació obrera. He wrote of the "perversity" of the Raval in Mirador, 23 May 1929.

86. See Justicia Social, I August 1931, I3 May, and 7 October 1933. According to the USC, anarchist mobilizations were "the action of the underworld, to which a minority of adventurers of working class origins had descended"; Justicia Social, 29 April 1933. 
dealers, pimps, and other anti-social types) to be labelled and amalgamated as if they formed a concerted campaign against the established order. ${ }^{87}$ Accordingly, the Raval's political and economic conflicts were criminalized, the anarchist movement placed on the same moral plane as the underworld, and a politically problematic community came to be defined in terms of public order. Crudely put, Chinatown provided an opportunity to alter popular attitudes towards the role of the state and justify state coercion: it reduced complex socio-economic and political questions to a problem of law and order. ${ }^{88}$ In practice, this legitimated a myriad of morality campaigns, reform plans, temperance drives, literacy initiatives, and, most of all, police repression. All these measures were designed to isolate the "deserving" poor from the "undeserving", the "respectable" from the "rough", and the "moderates" from "extremists". The "healthy" elements could then be safely coopted into "respectable" society, while the "degenerate and recalcitrant" elements would be subjected to measures of "social hygiene and cleansing". 89

The obsession with reordering Chinatown culminated in the 1934 "Macià Plan" $9 \circ$, a modernist blueprint for a "New Barcelona" (Barcelona nova) based on the violent destruction of the Raval in accordance with the new ideology of regional planning. ${ }^{91}$ Commissioned in spring 1932, the Macià Plan was a collaborative venture between a local technocratic thinktank, the Grup d'Arquitectes i Tècnics Catalans (Catalan Technicans' and Architects' Group/GATCPAC), and Le Corbusier, the Svengali of modernist urban-technocratic utopias. (The plan took its name after Le Corbusier met with Catalan President Macià - Le Corbusier's admiration of authority obliged him to name the project in honour of his patron. $)^{92}$ Inspired by Le Corbusier's maxim, "Architecture or Revolution. Revolution can be avoided", 93 the crux of the plan was the demolition of the Raval.

On one occasion, Lluís Companys, who succeeded Macià as Catalan

87. Thus, one conservative spoke of a "network of secret organizations" in this "crime zone", made up of foreign anarchists and "common criminals"; Fernando Barangó-Solís, Reportajes Pintorescos (Barcelona, I934), pp. I09-I I 3. For similar themes developed in the republican press, see La Publicitat, ro April 1934 .

88. For a classic discussion of this process in I 970 B Britain, see Stuart Hall, Chas Critcher, Tony Jefferson, John Clarke, and Brian Roberts, Policing the Crisis: Mugging, the State and Law and Order (London, 1978), who talk of the "mapping together" of "moral panics" into a "general panic" (pp. 218-227).

89. For examples of this language see Justicia Social, I 5, 22 July 1933, and L'Opinió, 2 I August, 2

December I931, 22 October 1933.

90. Francesc Roca, El Pla Macià (Barcelona, 1977).

91. Nicolau Rubió i Tudurí, Pla de distribució en zones del territori català (Barcelona, 1932).

92. Evidence of Le Corbusiers's increasingly authoritarian stance and his faith in the "strong idea" was his decisión to dedicate his 1935 work, La ville radieuse, "To authority"; Robert Fishman, Bourgeois Utopias (New York, 1987), pp. 236-237.

93. Ibid., p. I87. 
President in 1934, spoke in confidence to Josep Lluís Sert, one of Le Corbusier's disciples in Barcelona, of his desire to demolish the Raval "with cannon-shot". ${ }^{94}$ Yet Le Corbusier needed little encouragement: following a visit to the Raval during one of his trips to Barcelona, he was left appalled by the area's dense and insalubrious housing stock. The solution, Le Corbusier believed, lay in "mopping up" (esponjament) the Raval's streets and replacing them with a series of straight roads and major thoroughfares. ${ }^{95}$ In the technocratic utopia, the old city would be regenerated and the improved flow of goods, services, and people would bring "progress" and increased industrial power to the whole of Catalonia. Meanwhile, the former inhabitants of the Raval would be spirited away from the city centre to occupy modern, Bauhaus-style multistorey apartment blocks on the margins of Barcelona.

The Macià Plan remained on the drawing board: it was stymied both by budgetary problems and by the outbreak of the Spanish Civil War in 1936, after which it became a utopian dream of liberal middle-class planners. ${ }^{96}$ Commentators normally interpret the Macià Plan and its radical avantgarde supporters in the GATCPAC as being inspired by progressive, democratic, and anti-fascist ideas. ${ }^{97}$ However, closer analysis reveals that the Macià Plan and the GATCPAC obeyed a more traditional discourse and agenda. The GATCPAC denounced overcrowding in the Raval as a "cancer", $9^{8}$ employing medical language to draw attention to the "centres of infection" in Chinatown, which, it claimed, was a "clinical case". 99 Similarly, the Macià Plan typified the repressive undercurrent of Chinatown discourse. In fact, in its general outlines, the plan pursued cognate objectives to the Cerdà Plan. Equally, the Macià Plan resembled the nineteenth-century Hausmannization of Paris: both were appropriate to the economic and security requirements of the holders of social, economic, and political power of the day; both sought to drive major roads through the narrow, winding streets of working-class districts in order to facilitate the movement of commodities and, when necessary, the forces of public order. ${ }^{100}$ Indeed, the security dimensions of the Macià Plan are unmistak94. Cited in Salvador Tarragó, “'El 'Pla Macià' o 'La Nova Barcelona”, Cuadernos de Arquitectura y Urbanismo, 90 (1972), p. 29.

95. A. C., June 1937.

96. Jaume Fabre and Josep Maria Huertas, Tots els barris de Barcelona, 7 vols (Barcelona, 1976), vol. 5 , p. 65.

97. See Cristian Cirici, "Madrid-Barcelona. El nacimiento de dos metropolis modernas", in Xavier Bru de Sala (ed.), Barcelona-Madrid, I 898-1998: sintonías y distancias (Barcelona, I 997), pp. I47-I48, Oriol Bohigas, "Una arquitectura a la Catalunya republicana i autònomia", in Bru de Sala, Barcelona-Madrid, pp. 85-93; Josep Maria Rovira, "Los orígines del Plan Macià: entre la ciudad radiante y la ciudad funcional”, in Oyón, Vida obrera en la Barcelona de entreguerras, pp. $263-286$.

98. A.C., 25 June 1937.

99. GATCPAC, no. 6, I32.

I00. David Harvey, Consciousness and the Urban Experience (Oxford, 1985), pp. 63-220. 
able. It promised the pacification of the Raval through the "complete sterilization" ${ }^{\circ}$ or the "internal enemy" resident in the "district of the damned [...] in the heart of the city"; ${ }^{102}$ it was an essay in social and spatial exclusion, a brutal slum-clearance programme designed to destroy the randomly arranged, winding, narrow streets of the old city labyrinth easier to map and monitor by the state, while simultaneously forcing its insurgent population out of the city centre, dispersing it far away from the foci of economic and political power. In this case, Le Corbusier's oft-cited plan to "kill the street" ${ }^{\circ 3}$ meant expelling a historically rebellious community to newly designed spaces where it would be more easily contained and policed by the security forces. Meanwhile, the social networks and local solidarities that had sustained anti-capitalist resistance in the Raval would be disrupted.

Yet this was more than an attack on the Raval and its inhabitants: the planned demolition of the birthplace of the Barcelona working class was an act of aggression against a local history of proletarian resistance; it signified the destruction of key historical and symbolic spaces of the Barcelona working class, the elimination of the sites of memory of the resistance to capital, of demonstrations, riots, barricades, insurrections, and a whole array of protest behaviour that had taken place since the i 830 s. Spaces of struggle were to be replaced with major roads, places without history, around which new solidarities would be impossible. By obliterating these working-class memory spaces, the collective memory of struggle and identities contained within those spaces would also fade, and they would no longer serve as a source of inspiration to future generations of workers. ${ }^{104}$

\section{CONCLUSION}

Prophecies that "avenging angels" would burst forth from the Raval proved well-founded during the revolution that accompanied the start of the Spanish Civil War. ${ }^{105}$ Consequently, during the Franco dictatorship,

Iог. L’Opinió, I6 March I933; La Publicitat, I6 August 1933.

I02. El Escándolo, I 3 May and is July 1926.

I03. Le Corbusier, cited in Marshall Berman, All That Is Solid Melts Into Air: The Experience of Modernity (London, I983), p. 168.

I04. According to John Berger, these memories are a resource in the class struggle: "A people or a class which is cut off from its own past is far less free to choose and to act as a people or class than one that has been able to situate itself in history"; Ways of Seeing (Harmondsworth, 1972), p. 33 .

I05. See Chris Ealham, "The Myth of the 'Maddened Crowd': Class, Culture and Space in the Revolutionary Urbanist Project in Barcelona, I936-7”, in Chris Ealham and Michael Richards (eds), The Splintering of Spain: New Historical Perspectives on the Spanish Civil War (Cambridge, 2005). 
the Raval, like the rest of Barcelona, was singled out for punishment for its anti-clerical and revolutionary past. ${ }^{106}$ The elite collective memory of the spectre of Chinatown and the moral panics endured into post-Francoist democracy, when, before, during, and after the 1992 Barcelona Olympic Games, they provided inspiration for a new generation of urban planners who subjected the Raval's streets to a vicious process of urban reform and slum clearance. ${ }^{107}$ Today, gentrification and property speculation continue to undermine the Raval's spaces of working-class memory, forming part of a programme of social cleansing and middle-class colonization in the area. ${ }^{108}$ Yet the protest traditions of the Raval are enduring and the imposition of urban strategies from above continue to inspire the directaction collective resistance by groups rooted in the "Republic of the streets". ${ }^{109}$

I06. Manuel Vázquez Montalbán, Barcelonas (Barcelona, I990), ch. 5.

107. McNeill, Urban Change and the European Left, pp. 30-36.

ı08. Melissa Rossi, 'The Barcelona Model', Newsweek, 2 April 2004.

I09. In late February 2004 local resistance to plans to demolish a bar led to clashes between riot police and members of the community and patrons and friends of the bar owner; El Periódico, 27 February 2004. This protest action, and subsequent ones, were organized by the Coordinadora contra l'especulació del Raval (Co-ordinating Committee against Speculation in the Raval) and Arquitectos sin fronteras (Architects without Frontiers). 